IZA DP No. 6931

Immigrants' Time Use:

A Survey of Methods and Evidence

David C. Ribar

October 2012 


\title{
Immigrants' Time Use: A Survey of Methods and Evidence
}

\author{
David C. Ribar \\ University of North Carolina at Greensboro \\ and IZA
}
Discussion Paper No. 6931
October 2012

\author{
IZA \\ P.O. Box 7240 \\ 53072 Bonn \\ Germany \\ Phone: +49-228-3894-0 \\ Fax: +49-228-3894-180 \\ E-mail: iza@iza.org
}

Any opinions expressed here are those of the author(s) and not those of IZA. Research published in this series may include views on policy, but the institute itself takes no institutional policy positions. The IZA research network is committed to the IZA Guiding Principles of Research Integrity.

The Institute for the Study of Labor (IZA) in Bonn is a local and virtual international research center and a place of communication between science, politics and business. IZA is an independent nonprofit organization supported by Deutsche Post Foundation. The center is associated with the University of Bonn and offers a stimulating research environment through its international network, workshops and conferences, data service, project support, research visits and doctoral program. IZA engages in (i) original and internationally competitive research in all fields of labor economics, (ii) development of policy concepts, and (iii) dissemination of research results and concepts to the interested public.

IZA Discussion Papers often represent preliminary work and are circulated to encourage discussion. Citation of such a paper should account for its provisional character. A revised version may be available directly from the author. 
IZA Discussion Paper No. 6931

October 2012

\begin{abstract}
Immigrants' Time Use: A Survey of Methods and Evidence

This paper discusses research questions related to immigrants' time use, reviews conceptual and methodological approaches to examining time allocations, and reviews evidence from previous studies. It provides new descriptive evidence, using time-diary data from the American Time Use Survey. Although results vary with the country of origin, immigrant men in the U.S. tend to devote more time to market work and sleeping but less time to housework, community activities, and leisure than native men. Immigrant women tend to devote more time to housework, caregiving and sleep but less time to market work, community activities, and leisure than native women.
\end{abstract}

JEL Classification: J22, J61

Keywords: time use, immigrants

Corresponding author:

David C. Ribar

Department of Economics

University of North Carolina at Greensboro

Greensboro, NC 27408

USA

E-mail: dcribar@uncg.edu 


\section{IMMIGRANTS’ TIME USE: A SuRVEY OF METHODS AND EVIDENCE}

\section{INTRODUCTION}

Models of people's time use-principally the standard labor and human capital models but also more general time allocation models-are at the heart of economists' theories of immigrants’ behavior. However, time use has taken a back seat to other outcomes in empirical economic research on immigrants. Economic research has focused on outcomes that can be measured in terms of money, such as incomes, earnings, wage rates, public assistance benefits, tax payments, and remittances. Except for hours devoted to work, immigrants' time allocations have been at the center of only a few economic studies.

Immigrants’ uses of time have been studied by anthropologists, sociologists, geographers, family researchers, and health researchers. With the recent availability of large-scale time-use surveys, economists have also started to examine time use more comprehensively and make their own contributions. To continue that advancement, this paper discusses a host of research avenues related to immigrants' time use. It reviews several economic models of people’s time allocations and discusses their application to immigrant behavior. It also overviews methodologies for collecting time use data, their general research advantages, and some special considerations for immigrant studies. The paper also reviews evidence that has been generated using each of the approaches and illustrates methodological issues and provides new descriptive evidence, using time-diary data from the American Time Use Survey (ATUS). 


\section{WHY STUDY IMMIGRANTS' TIME USE?}

Considerations of time open many exciting research possibilities. First, analyses of time are interesting in their own right, as evidenced by some of the intriguing findings from general population studies. For example, Bianchi et al. (2000) documented an overall downward trend since the 1960s in the average total hours that U.S. women spend working. Women's work outside the home increased, but their work inside the home decreased. Bianchi (2000) also reported that the time American mothers spend caring for children has remained remarkably stable, even as mothers' time in paid employment has risen. Aguiar and Hurst (2007) similarly documented a net increase over the past 40 years in Americans' leisure but also found that leisure has become much less equally distributed with leisure increasing faster among lesseducated adults than more-educated adults. Aguiar and Hurst (2005) found that household production plays an important role in consumption smoothing and can resolve an empirical puzzle about large drops in people's expenditures shortly after retirement. Biddle and Hamermesh (1990) found that the amount of sleep that people obtain is sensitive to the wage rate that they receive for their labor market time, while Hamermesh et al. (2008) found that the amount of work that people perform is sensitive to the timing of late-night television shows and other cues that affect sleep. The diversity of findings in these studies and especially the heterogeneity of results across different groups suggest that extensions to populations of immigrants would be worthwhile.

Second, studies of time use can help to inform models of economic assimilation. As mentioned, empirical economic research has considered work times. Standard models of individual labor supply (see, e.g., Killingsworth 1983) and family labor supply (see, e.g., Becker 1981, Bergstrom 1996, and Chiappori 1988) predict that time devoted to work will depend on the 
effective price of that time (the wage rate) and other resources. Initial skill levels, including possible skills mismatches among secondary “tied workers” (Mincer 1978), can affect wage rates and thus incentives to work. Baker and Benjamin (1997) considered a "price" perspective in their analyses of immigrant married couples’ labor supply in Canada. Chiswick (1978) hypothesized that assimilation occurred through skills investments by immigrants that affected their earnings and hours profiles. Extending this analysis to a family context, Long (1980) investigated earnings and work hours profiles for immigrant wives and proposed a "family investment" framework in which borrowing constraints led wives to work more to finance the skills investments by their husbands. A gap in these studies is that the processes of assimilation, such as the time devoted to skills investments, have not been directly examined but instead been inferred from profiles of earnings and hours over time. Recent research by Hamermesh and Trejo (2010) begins to fill that gap by examining specific time-use inputs into assimilation.

Third, while skills, job opportunities, and borrowing constraints might affect the speed of immigrants' economic assimilation, other time demands could also act as barriers or constraints. Blazquez et al. (2010) and Preston et al. (1998) have each examined commuting time as a barrier to work and as a possible indicator of residential segregation and spatial mismatches in skill availability and needs. Qualitative and small-sample studies by Anastario and Schmalzbauer (2008), Bloch (1976), and Münscher (1984) indicate that household responsibilities may hinder women's economic assimilation. Extraordinary household responsibilities could also compete with the time that immigrant children are able to devote to school (Lee and Pacini-Ketchabaw 2011; Orellana 2001; Sarroub 2001; Zhou and Bankston 1994), interfering with the assimilation of the second generation. 
Fourth, studies of time use can also help us to understand assimilation in non-economic outcomes. Glick (2010) reviewed empirical research on immigrants’ assimilation and acculturation in family processes, including family formation, family structure, marital and nonmarital childbearing, parenting behavior, intergenerational relations, and family/work balance. Osili and Xie (2009) have examined assimilation in volunteering and other pro-social behaviors. Wingo et al. (2009) documented negative assimilation in health behaviors and physical health outcomes among female Mexican immigrants in the U.S.; Lara et al. (2005) reviewed additional studies on acculturation in health, and Escobar et al. (2000) reviewed evidence of negative assimilation in mental health outcomes. In this volume, MIGRANT OBESITY discuss research on obesity. Time inputs are relevant to all of these outcomes.

Fifth, the consideration of the special circumstances of immigrants can provide insights into standard economic models. Immigrants face institutional constraints that can be different from those of native-born people. For example, Orrenius and Zavodny (2009) have examined how immigration restrictions that the U.S. put in place after the September 11, 2001 terrorist attacks affected work behavior among Latin American immigrants. Cobb-Clark and Connolly (2001) investigated how differences in types of visas affected immigrants' labor supply in Australia. Information about preferences can also be gleaned from immigrants. Cortes (2004) has used refugee and economic immigrant status as indirect indicators for immigrants' time horizons and social networks in analyses of labor supply. Ward-Batts and Pabilonia (2007) have used information about different cultures' son-preferences to examine how the gender composition of children affects parents' work behavior. Cultural preferences have also figured in research by Zaiceva and Zimmermann (2007) on time spent in traditional and gendered activities. 
As this discussion indicates, research on immigrants' time use holds the promise of both deepening economists' understanding of immigrants' behavior and improving economists' models generally. However, much of that promise remains to be realized. The remainder of this paper highlights several conceptual and methodological tools as well as some preliminary evidence that can serve as building blocks for additional research.

\section{CONCEPTUAL APPROACHES FOR TIME USE}

Economists’ textbook model of individual labor supply (see, e.g., Killingsworth 1983) provides one way of analyzing time. The model distinguishes between time spent in two mutually-exclusive and exhaustive activities: paid work and all other "non-market” activities. Wages from paid work represent an effective price on time. As wage rates increase, non-market time becomes more expensive, causing people to substitute away from it. However, higher wages also increase total incomes for those who are employed, reducing their need to work.

Becker (1965) extended the standard labor supply model to consider multiple uses of time; his model serves as economists' "go to" conceptual framework for studying time use. Becker's insight was that the things that people ultimately care about, which he referred to as “commodities," such as meals, nice homes, and healthy children, require physical goods (or possibly services) and time to produce and enjoy. Becker posited that people use these inputs of goods and time to generate commodity outputs, much in the way that a factory would combine inputs of various factors to produce saleable outputs.

One implication of Becker's model is that people's time use in different activities is affected by the wage they can command in the labor market. By changing the price of time, wages affect both the mix of commodities that people choose and the mix of time and goods that

they put into the commodities. Other things held equal, people with low wages, such as newly- 
arrived unskilled immigrants, face a low price on time-intensive commodities, such as sleep and physical recreation. Also for a given commodity, people with low wages would be expected to substitute time for money, such as by choosing more time-consuming but less-expensive modes of travel. Time is also affected by the prices of goods, the productivity of the inputs in generating the commodities, and other resources of the individual.

Becker’s framework has been extended in a number of directions. Gronau (1977) considered a specialized version of the model that focused on household production. Becker (1981) discussed time allocations in a multiple-person household in which all of the members were subject to a single preference function, and Chiappori (1997) has considered time allocations in which household members have individual preferences but agree to pursue efficient outcomes. Becker's (1993) human capital model provides a dynamic analysis of time use with the investment of time in schooling, training, or other types of skills development competing with time spent working but also affecting subsequent productivity and wages. Grossman's (1972) health production model combined aspects of household production (health is a commodity that depends on time and goods inputs) and human capital (health contributes to productivity and current investments in health generate subsequent pay-offs). Coleman (1988) similarly developed a model of social capital that considered people's rational time investments in social relations and institutions.

To date, most research on immigrants' economic attainments has been motivated by standard labor supply or human capital models. However, there have been exceptions, including Hamermesh and Trejo (2010) and Zaiceva and Zimmermann (2011) who analyzed immigrants’ activities within general models of time allocation and Van Klaveren et al. (2006) who examined two-earner immigrant households using Chiappori’s (1997) collective model. 


\section{DATA ON TIME USE}

Empirical research on immigrants’ time use has used both primary data (data collected by the researchers themselves) and secondary data (data collected by one set of researchers and made available for others). With some exceptions, such as Anastario and Schmalzbauer (2008), the primary analyses have been qualitative, relying on data from semi-structured interviews and ethnographies. The secondary analyses have been quantitative and relied on data from largescale, general-population surveys that have either included recall questions about the time devoted to specified activities or time diaries that have respondents describe their activities over a specified period of time. Each of these approaches offers distinct advantages in studying immigrants’ time use.

\section{Qualitative Data}

Qualitative researchers conduct in-depth observations or interviews among carefully defined populations, encouraging subjects to describe their activities, circumstances, and other outcomes in their own words. This research emphasizes depth of data gathering about particular subjects over breadth in the number or diversity of subjects in a given study.

Because of the complexities in characterizing time use, this approach can be extraordinarily useful, as subjects can narrate both descriptions and context for their activities. Observations of these activities can provide additional context. In particular, qualitative descriptions can indicate whether an activity was perceived as pleasant or unpleasant, optional or required, easy or arduous, relaxing or stressful, singular or joint, and so on. The approach is especially helpful in immigrant research where investigators might not be familiar with the cultural context of activities. ${ }^{1}$ 
The principal drawback to qualitative methods is that they tend to be very time intensive. Given the constraints on researchers' resources, this often limits samples to a few dozen or less. Because of the small sample sizes, findings can be difficult to generalize to larger populations. At the same time, the textual data, such as field notes or interview transcripts, that are created from just a few cases can be difficult to summarize and compare. These drawbacks, however, may not be as limiting in immigrant research because immigrants’ minority status in most societies leads to small or enclaved groups, which reduce contextual variation and generalizability. Also, the unique and unfamiliar aspects of immigrants' circumstances require that researchers parse the available data especially carefully.

\section{Surveys with Recall Questions}

Many large-scale economic and social surveys include questions that ask respondents to recall the amount of time that they spent in specified activities in a particular period of time, "on average,” or usually over a given unit of time. For example, standard labor market surveys, such as the Current Population Survey (CPS) in the U.S. and the British Labour Force Survey (LFS) in the U.K., ask about weekly hours spent in market labor. The Decennial Censuses in the United States have asked (and the American Community Survey now asks) about usual weekly market work hours and minutes spent in a usual commute from home to work. Other surveys use recall questions to obtain more comprehensive descriptions of people’s daily activities. For example, the Household, Income and Labour Dynamics in Australia survey asks about weekly time spent in paid employment, commuting, household errands, housework, outdoor tasks, playing with own and others' children, volunteer and charitable activities, and care for elderly and disabled relatives. Similarly, the European Community Household Panel asked about weekly hours spent in paid employment, caring for children, and caring for ill, disabled or older persons. Yet other 
surveys ask about more specialized uses of time. For example, the National Health Interview Survey (NHIS) in the U.S. asks about hours spent sleeping, and special supplements to the NHIS have asked about time spent in healthy activities, such as walking for transportation and leisure.

The main advantages of recall questions along these lines are that they are short and easy to incorporate into a survey. This reduces the time burden on respondents and may allow researchers to include many other questions. It also reduces the cost of administering the survey, which may allow for more interviews and larger sample sizes. In addition, recall questions, such as the CPS work questions, can be easily replicated across surveys, which increases comparability and allows for validation. Because of these advantages, recall questions are widely used in time use research, and information from them, especially information about market work, has been extensively examined.

Juster et al. (2003) point out, however, that recall questions also have serious shortcomings. While the questions appear to be easy to answer, accurate responses actually require substantial cognitive effort as respondents attempt to recall the episodes of a type of activity, recall the durations of those episodes, and then sum the durations over the relevant time frame. The cognitive challenges are one reason why recall questions are typically constrained to a relatively short interval of time, such as a week. In addition, problems recalling interruptions in activities, such as a late arrival at work, can lead to over-reporting, while problems recalling infrequent activities can lead to under-reporting. Because the questions ask about specific activities, the responses may also be subject to "social desirability bias" in which subjects answer in ways that they believe others will approve of (Juster et al. give the example of educated parents over-reporting the time they spend reading to their children). 


\section{Time-diary surveys}

In a time diary, survey subjects are asked to recall and list all of the activities that they performed over some recent time interval, usually the preceding 24 hours. Borrowing a feature from qualitative research, respondents describe these activities in their own words; the descriptions are subsequently coded into a set of standardized categories using a detailed lexicon. Subjects are also asked the start and stop times of the activities. Respondents provide this information until a complete chronology of the time period is obtained.

The chief advantages of time diaries are that they tend to provide more accurate representations of people's activities over the specified period. The accuracy stems from the short recall period (which is usually limited to the previous 24 hours), the episodic format (which leads the respondent through the day and allows interviewers to prompt for breaks and inconsistencies in reporting), and the non-directed descriptions of activities (which removes interviewer cues regarding the social desirability of responses). Unlike recall questions, which are limited to the activities in the questions, time diaries allow subjects to report all of the activities that they performed. Other advantages are that additional characteristics of the activities, such as where they occurred and who else was present, can be readily obtained. Diaries can also gather information about other activities that are performed simultaneously (e.g., Zaiceva and Zimmermann 2011 use such data to examine joint production) or about people’s feelings and perceptions of activities (the ATUS added a "well-being” module in 2010).

Time diaries take longer to administer than a small set of recall questions. The time and cost of administration typically lead to smaller sample sizes (both by design and because of reduced subject cooperation) and fewer covariates. These size trade-offs can be seen in the ATUS. The sampling frame for the ATUS is the 7,500 households who complete their interview 
cycles with the CPS each month. Of those households, about 2,200 are randomly selected to be contacted by the ATUS, and of the subjects contacted, fewer than 60 percent participate. ${ }^{2}$ Another difference from the CPS is that the ATUS collects data from and about only a single person instead of all "adults” (people aged 15 and over) in a household. Time-diary surveys in other countries have collected more comprehensive data from households. For example, the United Kingdom Time Use Survey (UKTUS) administered diaries on two separate days to all people aged eight years and older in sampled households, and the Australian Time Use Survey administered diaries on two separate days to all people aged 15 and older in sampled households. ${ }^{3}$ However, neither of these surveys is conducted on an on-going basis, and each covered a much smaller sample than the ATUS (the 2000 UKTUS included about 6,400 households, and the 2006 Australian survey included 3,900 households).

As Borjas (1994) and others have discussed in other contexts, sample sizes are a critical issue in immigrant research because immigrants comprise a fraction of the population. A general population survey with a few thousand households might only include a few hundred immigrant households. Effective sample sizes are further squeezed if researchers disaggregate by gender or screen for other characteristics, such as marital status or work availability. Sample sizes would also be reduced if researchers wanted to focus on immigrants from a particular country or cultural background.

Time-diary surveys also often have fewer other data items (potential covariates) than recall surveys. For example, to keep the average administration time to 15-20 minutes, the ATUS asks respondents only a subset of the other economic and demographic questions typically asked in the core questionnaire of the monthly CPS (however, information from the ATUS can be linked to earlier CPS responses, partly mitigating this shortcoming). 
Finally, time-diary data tend to be highly variable, mostly reflecting the fact that they only cover one or a few days. Juster et al. describe this in terms of inter-day reliability-if a diary is administered to the same person on several different days during a year, the responses are likely to vary across days. Differences in times reported in weekday and weekend activities are the most notable example. However, there also appear to be differences in reliability by the type of activity. Juster et al. report that regular, frequently performed activities, such as market work, tend to be reported much more reliably than irregular or infrequently performed activities, such as home repairs. Combined with the modest sample sizes that we have already discussed, the high variability in time-diary data can substantially reduce the statistical power of quantitative analyses.

\section{FINDINGS FROM QUALITATIVE STUDIES}

There have been qualitative investigations of the time use of immigrant men. For example, Kilkey and Perrons (2010) and Perrons et al. (2010) have recently interviewed 25 immigrant handymen from Central and Eastern Europe living and working in the U.K., where self-employed handyman work represents an interesting niche market. Consistent with an investment framework, the researchers found that the time immigrant men spent working in and establishing these businesses limited the time and energy that they had to help with their own families, even as it allowed more-educated U.K.-born men to spend time with their children.

Although qualitative research has yielded insights into men's time use, it has been especially valuable in helping to understand the experiences of immigrant women and children. Bloch’s (1976) ethnography of married women from a rural sending community in Poland and receiving communities in New Jersey illustrates the complexity of studying immigrant behavior. The women's circumstances in the sending community were unique in the sense that they had 
tremendous responsibilities in both the household and the farm and also had unusual levels of economic decision-making power, owing to the structure of dowries in the community. In the receiving community, women's roles shifted as they began working long hours in low-skilled jobs outside the home. Despite high continuing household demands and expectations, the women's job responsibilities crowded out family meals, other time with the family, and traditional socialization, leading to isolation. At the same time, the women's earnings helped them to continue patterns of economic autonomy within their households.

Münscher’s (1984) semi-structured interviews with working Turkish women in Munich revealed similar issues of long hours in poorly paid work crowding out household work, increasing the women's time stress, and also increasing household responsibilities for children. A distinctive part of Münscher's findings, however, was the role played by the institutional context, notably German restrictions and waiting periods on work permits for immigrant family members. Besides creating economic hardships, these policies meant that many of the women were the primary or only earners in their families and that many headed or had been a part of households that were split between Germany and Turkey.

Findings of large (and gendered) household demands on immigrant children have also been reported in qualitative studies. Lee and Pacini-Ketchabaw (2011) documented levels of caregiving for younger siblings that ranged from seven to 37 hours per week among immigrant girls in Vancouver. Orellana’s (2001) ethnography of Mexican and Central American immigrant grade-school children in California not only revealed substantial amounts of time devoted to chores and caregiving but also indicated that some children participated in piecework market labor that was brought into the household. Sarroub (2001) described enormous household responsibilities placed on Yemeni high school girls living in Detroit and unique cultural 
demands—most of the girls were engaged or married by age 14 or 15 . All of these studies also describe responsibilities that the children had serving as translators and cultural intermediaries for other family members.

Household demands notwithstanding, the skills investment orientations of immigrant adults often also extend to their children. Sarroub described how the Yemeni girls devoted themselves to schooling, including special classes in Arabic on nights and weekends and time spent as tutors in a community center. Similarly, in a case study by Zhou and Bankston (1994) of Vietnamese youth in New Orleans, about 70 percent of girls and 40 percent of boys reported often or always helping with housework, yet most also found time to complete homework each day. Values regarding caregiving, help, and school were emphasized within the families but also reinforced by extended family and kin networks.

The picture that emerges from the qualitative research is one of industriousness but with efforts allocated differently among paid labor, housework and caregiving, and (in the case of children) schooling. Another theme from the qualitative research is the diversity of circumstances that arise from differing cultural contexts (especially cultural expectations of gender roles), skill sets and needs, institutional constraints, and family processes. This diversity provides a caution to quantitative researchers that there are many potential confounding and hard-to-measure influences on immigrants' time use and that immigrants' behavior is likely to be heterogeneous. 


\section{FINDINGS FROM RECALL-QUESTION SURVEYS}

\section{Work hours}

As mentioned, numerous economic studies have empirically investigated the hours of work that immigrants perform. Nearly all of this research has relied on large-scale surveys with recall questions asking about work hours in the previous week or in a usual week.

Carliner’s (1980) influential study of immigrant men’s economic attainments compared data on annual work hours from the 1970 Decennial Census in the U.S. across recent immigrants who had arrived in the preceding five years, immigrants who had arrived earlier, the children (second generation) of immigrants, and the children (third and higher generations) of U.S.-born parents. ${ }^{4}$ Carliner further disaggregated by eight different groups defined in terms of their races, ethnicities, and countries of origin. For all racial and ethnic groups, annual hours of work were lower for recent immigrants than for immigrants who had been in the country longer. For most groups, the annual hours of third-generation Americans were also lower than the long-tenured immigrants. Second-generation men generally worked more hours than recent immigrants and third-generation men. Drawing on standard labor theory, Carliner speculated that stronger preferences for consumption and relatively weak preferences for leisure and family time might account for the labor supply patterns.

Long (1980) also used the 1970 Decennial Census, but examined earnings and work hours for white immigrant women. He found that foreign-born white women worked fewer annual hours than U.S.-born white women and that the difference widened the longer the immigrant women remained in the country. He also found that the foreign-born women had flat tenure-earnings profiles. The hours and earnings results led him to propose the "family investment hypothesis.” Schoeni (1998) conducted a more detailed and comprehensive analysis 
of immigrant women's work hours, drawing on data from the 1970, 1980 and 1990 Decennial Censuses. In contrast to Long's analysis, Schoeni examined all working-age immigrant women, not just white women, and as with Carliner's study, Schoeni also examined relationships separately for groups defined in terms of countries of origin. Among this more general group of women, immigrants worked more than U.S.-born women, although there were differences depending on the country of origin. Immigrant women from the Philippines worked more hours than other women, but immigrants from the U.K., Canada, and Mexico worked less. Schoeni’s results provide yet another caution against pooling data for different immigrant groups and effectively treating them as a single demographic group.

Additional examinations of immigrant women's labor supply from recall data in different countries have tended to support the family investment hypothesis. These include studies by Duleep and Sanders (1993) of married Asian, European and Canadian women in the U.S. using data from the 1980 Decennial Census, Baker and Benjamin (1997) of immigrant men and women using data on annual hours from the 1986 and 1991 Canadian Surveys of Consumer Finances, Worswick (1999) of immigrant women using data on annual hours from the 1981 and 1991 Canadian Censuses, and Cobb-Clark and Connolly (2001) of new immigrant spouses in the Longitudinal Survey of Immigrants to Australia. However, there have also been findings that have run counter to the hypothesis, including the evidence by Blau et al. (2003) for immigrant women in the U.S. and findings by Lozano (2010) that immigrant men are less likely than U.S.born men to work long hours.

Researchers have used data on immigrants' work hours to investigate other aspects of labor supply models. Dustmann and Fabri (2005) examined the heterogeneity of immigrant couples' labor supply conditional on their ethnicity and the husbands' earnings potential in the 
U.K. using the LFS. They found that non-white immigrant husbands and wives worked more than white natives and that the labor supply differences were largest for households where the husbands had the lowest wages. Cobb-Clark and Connolly (2001) used Australian data, and Cortes (2004) used U.S. data to examine how immigrants' work hours varied with their reasons for immigrating (e.g., economic, refugee, family reunification). Refugees were hypothesized to have longer time horizons for skills investments because of the impossibility of return migration. Cobb-Clark and Connolly found few differences between different types of immigrants once they controlled for other observed factors, but Cortes found that refugees had steeper tenurehours profiles than economic immigrants.

Ward-Batts and Pabilonia (2007) investigated how the presence of very young sons affects married immigrant fathers' and mothers' labor supply, using data from the CPS. They distinguished between immigrants from countries with strong son preferences, such as Asian countries. They found some evidence that son preferences translated into lower work hours for fathers.

Orrenius and Zavodny (2009) used data from the CPS to investigate the effects of post9/11 work restrictions on employment outcomes for young, low-skill Latin American men. They found that the work hours for these men decreased relative to other groups after the September 11, 2001 terrorist attacks.

\section{Other activities}

Housework and leisure. Van Klaveren et al. (2006) estimated a structural model of Dutch couples' market work, housework, and leisure hours based on Chiappori’s (1997) collective household production approach. Their data included Turkish immigrants, Surinamese/Antillean immigrants, and Dutch natives. The parameter estimates from their models indicated that 
women, and especially immigrant women, placed high values on leisure and household production. They also found that Turkish and Dutch households placed relatively high weights on the utility of males rather than females.

Commuting times. Preston et al. (1998) examined commuting times for immigrants and natives living in counties in and around New York City, using recall data from the 1990 Decennial Census. They found that reported commutes were longer for immigrants than for natives but that differences associated with gender, race and ethnicity exceeded those associated with nativity status. Blazquez et al. (2010) investigated commuting times for Madrid using data from the 2001 Spanish census. They found that immigrants from Africa, Columbia, Ecuador, and eastern Europe had longer commutes than native Spaniards, but that immigrants from other countries did not have longer commutes.

Volunteering. Osili and Xie (2009) studied reports of immigrants' time transfers that were collected as part of the volunteer supplement to the 2001 Panel Study of Income Dynamics (PSID), the 2002 Child Development Supplement to the PSID, and the volunteer supplement to the September 2003 CPS. Their research indicated that immigrants in the U.S. were less likely to volunteer in their communities and spent less time volunteering. They also found some evidence that immigrants assimilated in their volunteering behavior; newly arrived immigrants volunteered much less than older immigrants.

Children's exercise and physical activity. Gordon-Larsen et al. (2003) examined rates of physical activity and other health behaviors among Latin American immigrant children in the U.S., using the National Longitudinal Study of Adolescent Health. Their estimates indicated that U.S.-born children were more likely to have very low rates of physical activity than firstgeneration Mexican immigrant children, and that this and other behaviors contributed to lower 
rates of obesity for Mexican immigrant children. They also found evidence of acculturation in health behaviors and obesity. Taverno et al. (2010) obtained different results when they investigated data on 6-11 year-old children in the U.S. from the National Survey of Children's Health. Taverno et al. found that first-generation, non-English-speaking immigrant children were less likely to participate in physical activity and sports than U.S.-born children but also spent less time in front of television and computer screens. Besides the differences in ages, differences in the way that physical activity was defined could explain the disparity in findings.

Sleep. Hale and Rivero-Fuentes (2011) compared usual-day sleep durations for Mexican immigrants and U.S.-born people of Mexican ancestry, using recall data from the 1990 National Health Interview Survey. They found that immigrants were less likely to have too-short sleep spells, but they also found evidence that immigrants' sleep patterns acculturated to natives’ patterns.

\section{EVIDENCE FROM TIME-DIARY STUDIES}

Only a handful of time-diary studies have focused on outcomes for immigrants. Anastario and Schmalzbauer (2008) piloted a one-week time-diary study within an ethnography of 34 Honduran immigrants with work histories in Chelsea, Massachusetts. The time diaries revealed that the immigrants worked long hours and that the work was gendered. Honduran men spent 8.0 hours per day (including weekends) in paid work and commuting, 1.4 hours in housework and caregiving, and 3.4 hours in leisure, while Honduran women spent 6.1 hours per day in paid work and commuting, 5.6 hours in housework and caregiving, and 1.1 hours in leisure. Interviews indicated that the subjects felt tremendous time pressure and viewed themselves as making strong sacrifices for their families in the U.S. and in Honduras. 
Two unpublished studies have used the ATUS to examine immigrants' time use. Vargas and Chavez (2010) compared outcomes for first-, second-, and third-generation married, working-age Mexican immigrants to those of non-Hispanic, U.S. natives, using 2003-2009 data from the ATUS. Vargas and Chavez classified daily activities into ten mutually exclusive and exhaustive categories. They found that first-generation Mexican immigrant husbands devoted more time than their non-Hispanic, white, U.S.-born counterparts to paid employment, commuting, purchasing, and sleep and less time to leisure, exercise, eating, housework, and caregiving. First-generation immigrant wives devoted more time than non-Hispanic, white, U.S.born wives to housework, caregiving, and sleep and less time to paid work, commuting, leisure, and exercise. Vargas and Chavez found evidence of intergenerational assimilation but no consistent evidence of intertemporal assimilation.

Using 2004-2008 data from the ATUS and 1992 data from the Australian Time Use Survey, Hamermesh and Trejo (2010) focused on immigrants' assimilating activities, which they defined as work, education, and purchasing. Hamermesh and Trejo considered all immigrants together (they did not distinguish by region or country of origin); they also examined all survey respondents (they did not limit their analysis to working-age or married adults). They found that immigrants were less likely to engage in an assimilating activity but conditional on participating, that immigrants spent more time in these activities. They attributed the difference in the participation and intensity findings to large fixed costs for immigrants from engaging in these activities.

Two other studies have investigated ethnic minorities' time use using the UKTUS. Zaiceva and Zimmermann (2007) examined ethnic differences in the time devoted to stereotypically female activities of child care, food management, and religious observance. They 
found that ethnic-minority women in the U.K. spent more time than white women cooking and in religious activities. They also found that ethnic-minority men in the U.K. spent less time than white men in child care and food management but more time in religious activities. Using data from the UKTUS on secondary activities, Zaiceva and Zimmermann (2011) investigated whether ethnic minorities were more likely to engage in joint production, as this would be one strategy for time-pressed ethnic minorities to "stretch" their available time. They found, however, that white men and women spent more time in joint production than ethnic minorities.

Another study has focused on children. Hofferth and Moon (2010) examined data on children's activities and achievement from the 2003 and 2007 Child Development Supplements to the PSID. The activities included time spent in video games, computer games, television, visiting, reading, studying, housework, sports, and music. In multivariate analyses, they found that first- and second-generation immigrant children spent less time than other children playing video games and more time reading and studying.

\section{EVIDENCE FROM THE ATUS}

To document the general patterns of immigrants' time use in the U.S. and to show differences by nativity status, I examine 2003-2010 data from the ATUS. As with the study by Hamermesh and Trejo (2010), I initially consider all of the respondents to the ATUS, but unlike them, I calculate statistics separately for people who are (a) working-age (21-64 years old) but neither full-time students nor retired, (b) youths (15-20 years old) and full-time students, and (c) older adults (65 years and older) and retirees. As with the study by Vargas and Chavez (2010), I also consider a set of mutually-exclusive and exhaustive activities, though the specific categorizations differ from their study. The specific activities that I consider are market work (including commuting time and work-related travel), household work (including shopping and 
civic responsibilities), caregiving for children, the elderly, and disabled people inside and outside the home, community and religious activities, leisure, sleep, other identified activities, and the balance of time that could not be identified (effectively missing data in the time diaries). The selections of analysis samples and the classifications of activities are intended to show all of the diary reports that are available in the ATUS. For all of my analysis, I incorporate survey weights provided with the multiple-year files of the ATUS that address sample design issues and nonresponse.

Table 1 lists the averages of the hours that foreign-born respondents (first-generation immigrants), U.S.-born respondents with foreign-born parents (second-generation immigrants), and U.S.-born respondents with U.S.-born parents (third-generation) report spending each week in different activities. ${ }^{5}$ The three columns of figures on the left list averages for men, while the three columns on the right list averages for women. The table is divided into three panels with the top panel listing estimates for working-age adults, the middle panel listing estimates for youths and students, and the bottom panel listing estimates for older adults and retirees. Relevant (unweighted) sample sizes are also listed.

\section{[Table 1 about here]}

From Table 1, we see that the large sample for the 2003-2010 ATUS (over 112,000 diaries) supports analyses of immigrants that are disaggregated by own and parents' nativity status, age group, and gender. The ATUS includes 13,850 diaries from first-generation immigrants (12.4 percent of the sample) and 9,097 diaries from second-generation immigrants (8.1 percent of the sample). The working-age group is largest with 11,061 first-generation immigrants, 4,796 second-generation immigrants, and 62,313 natives. However, the youth and older-adult samples are also moderately large. 
Consistent with the evidence from many of the recall-question studies, the estimates in the top panel of Table 1 indicate that foreign-born working-age men work more hours in the labor market and foreign-born working-age women work less than their U.S.-born counterparts. Consistent with the recall-question results from Hale and Rivero-Fuentes (2011), first-generation working-age men and women sleep more than their third-generation counterparts. The ATUS data indicate that first-generation working-age men spend less time in housework, community and religious activities, and leisure but more time in education than third-generation men, while first-generation working-age women spend less time in community and religious activities and leisure but more time in household work, caregiving, and education than third-generation women. There is also evidence that first-generation working-age immigrants provide slightly less usable time-diary information than third-generation men and women.

For working-age men, there is evidence of intergenerational assimilation. Secondgeneration immigrant men spend less time in housework and more time in education than thirdgeneration men. However, their time devoted to other activities is statistically indistinguishable from third-generation men. The patterns for second-generation women are more varied. For caregiving, education, and leisure, their time use is between the first and third generations, and for sleep, their time use is identical to third-generation women. However, for market work, household work, and community and religious activities, second-generation women's time use is distinct.

In the results for youths, first-generation males spend less time in community and religious activities and in leisure but more time sleeping than third-generation male youths. Firstgeneration females spend more time in market work and education but less time in leisure and sleeping than third-generation females. Second-generation males spend less time in market work 
and housework but more time in education than third-generation males. Second-generation females spend less time in market work and leisure but more time in housework and education than third-generation females. In general, the results buttress qualitative findings of larger educational investments by immigrant children but provide less support for qualitative findings of enormous work responsibilities.

Consistent with the findings of Aguiar and Hurst (2005), older men and women, regardless of nativity status, report relatively large amounts of time in housework. Older firstgeneration immigrant men report less housework and more market work than older thirdgeneration men, while older first-generation women report more housework than older third generation-women. Older first-generation immigrants also report less leisure but more sleep than older third-generation Americans.

Previous results from Blazquez et al. (2010), Schoeni (1998) and others indicate that immigrant groups should also be examined separately. Because of modest sample sizes, it is not practical to disaggregate the youth or elderly samples from the ATUS. However, the workingage sample can be broken out by sending country. Table 2 reports weekly time use among firstgeneration immigrants separately by gender and by sending country for the nine largest sending countries in the ATUS.

[Table 2 about here]

Among first-generation working-age immigrants, the largest proportion (just over a third) comes from Mexico. The numbers of observations for other sending countries are much smaller; nevertheless, the sample sizes are sufficient to confirm that there is tremendous diversity in time use patterns. For example, Cuban, Salvadoran, and Indian immigrant men work substantially more than Mexican immigrant men, but Filipino men work less. Salvadoran and Indian men 
perform less housework than Mexican men, but men from the U.K. and the Philippines perform more. Filipino men also provide more caregiving than Mexican men, as do Chinese men. Filipino and Chinese men also spend more time in education activities than Mexican men.

Mexican immigrant women perform less market work and more housework than all of the other groups, with most of the differences being statistically significant. Cuban, Salvadoran, German, U.K., and Filipina immigrant women provide less caregiving than Mexican women, but Indian immigrant women provide more. There is more than an hour's daily difference in the ranges of leisure and sleep among the groups of women.

\section{CONCLUSIONS}

Economic research on immigrants' time use has focused on market work behavior—and as it turns out, for good reasons. As a practical matter, data on market work are more widely available than data on other uses of time, facilitating research in this area. More fundamentally, economists hypothesize that work behavior is a key mechanism in economic assimilation, and empirical research has documented that immigrant men and, in many cases, immigrant women work long hours in the labor market to take advantage of the job opportunities in their new countries.

Data from other disciplines, including qualitative studies, recall-question surveys, and time-diary surveys, extends and deepens that understanding. In studies that are able to consider market work, non-market work, and skills investment, the general conclusion of immigrant industriousness is strengthened.

Another lesson, however, also emerges from the research and evidence on immigrants' time use: diverse groups in diverse contexts produce diverse results. As tempting as it might be to try to offer one over-arching description or one pattern for immigrants' behavior, we must be 
mindful of the tremendous heterogeneity in outcomes and relationships. Immigrant time use tends to be more gendered than native behavior in developed countries. In addition, time use varies depending on the country of origin. Small samples and the need for statistical power will tempt researchers to pool samples and to include simple controls for nativity status. Findings from studies that have had the luxury of larger samples, including the descriptive evidence presented in this paper, show that this temptation must be resisted.

While diversity among immigrant groups challenges researchers, it also presents tremendous opportunities. Qualitative studies show that there are (or have been) unique cultural contexts — economic autonomy for rural Polish wives, early arranged betrothals and marriages for Yemeni girls, extended kin networks in several ethnic and immigrant groups—-that would provide fascinating and useful contrasts with either natives or other immigrant groups. Institutional constraints, including residential segregation, work rules, and visa quotas, provide other ways to test general economic approaches. The multiplicity of time-use outcomes only adds to the behaviors and relationships that can be examined.

The variety of time use data sources also opens possibilities for economic research. While time-diary surveys have many advantages, data on time allocations for a host of activities, ranging from volunteering activity to caregiving to health behaviors, are also available in largescale recall surveys, including some longitudinal surveys. These sources have been used by other disciplines but remain ripe for economic analysis. 


\section{REFERENCES}

Aguiar, Mark and Erik Hurst (2005), 'Consumption versus expenditure’, Journal of Political Economy, 113(5), 919-48.

Aguiar, Mark and Erick Hurst (2007), 'Measuring trends in leisure: the allocation of time over five decades', Quarterly Journal of Economics, 122(3), 969-1006.

Anastario, Michael and Leah Schmalzbauer (2008), 'Piloting the time diary method among Honduran immigrants: gendered time use', Journal of Immigrant and Minority Health, 10(5), 437-443.

Baker, Michael and Dwayne Benjamin (1997), ‘The role of the family in immigrants’ labormarket activity: an evaluation of alternative explanations', American Economic Review, 87(4), 705-27.

Becker, Gary S. (1965), ‘A theory of the allocation of time’, Economic Journal, 75(299), 493517.

Becker, Gary S. (1981), A Treatise on the Family, New York: Cambridge University Press.

Becker, Gary S. (1993), Human Capital: A Theoretical and Empirical Analysis with Special Reference to Education, $3^{\text {rd }}$ edition, Chicago, IL: University of Chicago Press.

Bergstrom, Theodore C. (1996), “Economics in a family way', Journal of Economic Literature, 34(4), 1903-34.

Bianchi, Suzanne M. (2000), 'Maternal employment and time with children: dramatic change or surprising continuity', Demography, 37(4), 401-14.

Bianchi, Suzanne M., Melissa A. Milkie, Liana C. Sayer and John P. Robinson (2000), 'Is anyone doing the housework? trends in the gender distribution of household labor', Social Forces, 79(1), 191-228. 
Biddle, Jeff E. and Daniel S. Hamermesh (1990), 'Sleep and the allocation of time’, Journal of Political Economy, 98(5), 922-43.

Blau, Francine D., Lawrence M. Kahn, Joan Y. Moriarty and Andre Portela Souza (2003), 'The role of the family in immigrants' labor market-activity: an evaluation of alternative explanations: comment', American Economic Review, 93(1), 429-47.

Blazquez, Maite, Carlos Llano and Julian Moral (2010), 'Commuting times: is there any penalty for immigrants’, Urban Studies, 47(8), 1663-86.

Bloch, Harriet (1976), 'Changing domestic roles among Polish immigrant women’, Anthropological Quarterly, 49(1), 3-10.

Borjas, George (1994), 'The economics of immigration', Journal of Economic Literature, 32(4), $1667-1717$.

Carliner, Geoffrey (1980), 'Wages, earnings and hours of first, second, and third generation American males’, Economic Inquiry, 18(1), 87-102.

Chiappori, Pierre-Andre (1988), 'Rational household labor supply’, Econometrica, 56(1), 63-90.

Chiappori, Pierre-Andre (1997), 'Introducing household production in collective models of labor supply’, Journal of Political Economy, 105(1), 191-209.

Chiswick, Barry R. (1978), 'The effect of Americanization on the earnings of foreign-born men', Journal of Political Economy, 86(5), 897-921.

Cobb-Clark, Deborah A. and Marie D. Connolly (2001), ‘A family affair: the labor market experience of immigrant spouses’, Social Science Quarterly, 82(4), 796-811.

Coleman, James S. (1988), 'Social capital in the creation of human capital', American Journal of Sociology, 94(Supplement), S95-S120. 
Cortes, Kalena E. (2004), ‘Are refugees different from economic immigrants? Some empirical evidence on the heterogeneity of immigrant groups in the United States', Review of Economics and Statistics, 86(2), 465-80.

Duleep, Harriet Orcutt and Seth Sanders (1993), 'The decision to work by married immigrant women’, Industrial and Labor Relations Review, 46(4), 677-90.

Dustmann, Christian and Francesca Fabri (2005), 'Gender and ethnicity—married immigrants in Britain', Oxford Review of Economic Policy, 21(3), 462-84.

Escobar, Javier I., Constanza Hoyos Nervi and Michael A. Gara (2000), ‘Immigration and mental health: Mexican Americans in the United States', Harvard Review of Psychiatry, 8(2), 64-72.

Eurostat (2009), ‘Harmonised European time use surveys’, Eurostat methodologies and working papers KS-RA-08-014-EN-N, Office for Official Publications of the European Communities, Luxembourg.

Glick, Jennifer E. (2010), ‘Connecting complex processes: a decade of research on immigrant families', Journal of Marriage and the Family, 72(3), 498-515.

Gordon-Larsen, Penny, Kathleen Mullen Harris, Dianne S. Ward and Barry M. Popkin (2003), 'Acculturation and overweight-related behaviors among Hispanic immigrants to the US: the National Longitudinal Study of Adolescent Health', Social Science and Medicine, 57(11), 2023-34.

Gronau, Reuben (1977), 'Leisure, home production, and work—-the theory of the allocation of time revisited', Journal of Political Economy, 29(6), 1099-123.

Grossman, Michael (1972), 'On the concept of health capital and the demand for health', Journal of Political Economy, 80(2), 223-55. 
Hale, Lauren and Estela Rivero-Fuentes (2011), 'Negative acculturation in sleep duration among Mexican immigrants and Mexican Americans’, Journal of Immigrant and Minority Health, 13(5), 402-7.

Hamermesh, Daniel S., Caitlin Knowles Myers and Mark L. Pocock (2008), 'Cues for timing and coordination: latitude, Letterman, and longitude', Journal of Labor Economics, 26(2), 233-46.

Hamermesh, Daniel S. and Stephen J. Trejo (2010), 'How do immigrants spend their time? the process of assimilation’, IZA Discussion Paper 5010, Institute for the Study of Labor, Bonn.

Hofferth, Sandra L. and Ui J. Moon (2012), 'Class, culture, and activity choice: divergent pathways to achievement among children of immigrant and U.S.-born parents’, mimeo, University of Maryland, College Park, MD.

Juster, F. Thomas, Hiromi Ono and Frank P. Stafford (2003), 'An assessment of alternative measures of time use', Sociological Methodology, 33, 19-54.

Kilkey, Majella and Diane Perrons (2010), 'Gendered divisions in domestic work time: the rise of the (migrant) handyman phenomenon,' Time \& Society, 19(2), 239-64.

Killingsworth, Mark R. (1983), Labor Supply, New York: Cambridge University Press.

Lara, Marielena, Cristina Gamboa, M. Iya Kahramanian, Leo S. Morales and David E. Hayes Bautista (2005), 'Acculturation and Latino health in the United States: a review of the literature and its sociopolitical context', Annual Review of Public Health, 26, 367-97.

Lee, Jo-Anne and Veronica Pacini-Ketchabaw (2011), 'Immigrant girls as caregivers to younger siblings: a transnational feminist analysis’, Gender and Education, 23(2), 105-19. 
Long, James E. (1980), ‘The effect of Americanization on earnings: some evidence for women”, Journal of Political Economy, 88(3), 620-29.

Lozano, Fernando A. (2010), 'Understanding the workweek of foreign born workers in the United States', Review of Economics of the Household, 8(1), 83-104.

Mincer, Jacob (1978), 'Family migration decisions', Journal of Political Economy, 86(5), 74973.

Münscher, Alice (1984), 'The workday routines of Turkish women in Federal Republic of Germany: results of a pilot study', International Migration Review, 18(4), 1230-46.

Orellana, Marjorie F. (2001), ‘The work kids do: Mexican and Central American immigrant children's contributions to households and schools in California', Harvard Educational Review, 71(3), 366-89.

Orrenius, Pia M. and Madeline Zavodny (2009), 'The effects of tougher enforcement on the job prospects of recent Latin American immigrants', Journal of Policy Analysis and Management, 28(2), 239-57.

Osili, Una O. and Jia Xie (2009), 'Do immigrants and their children free ride more than natives?', American Economic Review, 99(2), 28-34.

Perrons, Diane, Ania Plomien and Majella Kilkey (2010), “Migration and uneven development within an enlarged European Union: fathering, gender divisions and male migrant domestic services”, European Urban and Regional Studies, 17(2), 197-215.

Preston, Valerie, S. McLafferty and X. F. Liu (1998), 'Geographical barriers to employment for American-born and immigrant workers', Urban Studies, 35(3), 529-45. 
Taverno, Sharon E., Brandi Y. Rollins and Lori A. Francis (2010), ‘Generation, language, body mass index, and activity patterns in Hispanic children', American Journal of Preventive Medicine, 38(2), 145-53.

Sarroub, Loukia K. (2001), 'The soujourner experience of Yemeni American high school students: an ethnographic portrait', Harvard Education Review, 71(3), 390-415.

Schoeni, Robert F. (1998), 'Labor market outcomes of immigrant women in the United States: 1970 to 1990', International Migration Review, 32(1), 57-77.

Van Klaveren, Chris, Bernard M. S. van Praag and Henriette Maassen van den Brink (2006), 'A collective household model of time allocation: a comparison of native Dutch and immigrant households in the Netherlands’, CESifo Working Paper 1753, CESifo, Munich.

Vargas, Andres J. and Manuel Chavez (2010), ‘Assimilation effects beyond the labor market: time allocations of Mexican immigrants to the U.S.', mimeo, Texas Tech University, Lubbock, TX.

Ward-Batts, Jennifer and Sabrina Pabilonia (2007), 'The effect of child gender on parents’ labor supply: an examination of natives, immigrants, and their children', American Economic Review, 38(2), 402-6.

Wingo, Phyllis A., Aniket Kulkarni, Lori G. Borrud, Jill A. McDonald, Susie A. Villalobos and Diane C. Green (2009), 'Health disparities among Mexican American women aged 15-44 years: National Health and Nutrition Examination Survey, 1999-2004', American Journal of Public Health, 99(7), 1300-07.

Worswick, Christopher (1999), 'Credit constraints and the labour supply of immigrant families in Canada', Canadian Journal of Economics, 32(1), 152-70. 
Zaiceva, Anzeklia and Klaus F. Zimmermann (2007), 'Children, kitchen, church: does ethnicity matter?’, IZA Discussion Paper 3070, Institute for the Study of Labor, Bonn.

Zaiceva, Anzelika and Klaus F. Zimmermann (2011), ‘Do ethnic minorities ‘stretch’ their time? UK household evidence on multitasking', Review of Economics of the Household, 9(2), 181-206.

Zhou, Min, and Carl L. Bankston III (1994), 'Social capital and the adaptation of the second generation: the case of Vietnamese youth in New Orleans’, International Migration Review, 28(4), 821-45. 
Table 1 Weekly hours in different activities in the U.S. by gender and nativity, 2003-10

\begin{tabular}{|c|c|c|c|c|c|c|}
\hline \multirow[b]{2}{*}{ Activity } & \multicolumn{3}{|c|}{ Men } & \multicolumn{3}{|c|}{ Women } \\
\hline & $\begin{array}{l}\text { Foreign- } \\
\text { born }\end{array}$ & $\begin{array}{c}\text { Native with } \\
\text { foreign-born } \\
\text { parents } \\
\end{array}$ & $\begin{array}{c}\text { Native with } \\
\text { native } \\
\text { parents } \\
\end{array}$ & $\begin{array}{l}\text { Foreign- } \\
\text { born }\end{array}$ & $\begin{array}{c}\text { Native with } \\
\text { foreign-born } \\
\text { parents } \\
\end{array}$ & $\begin{array}{c}\text { Native with } \\
\text { native } \\
\text { parents }\end{array}$ \\
\hline \multicolumn{7}{|c|}{ WORKING-AGE ADULTS (AGES 21-64 YEARS) WHO ARE NOT FULL-TIME STUDENTS OR RETIREES } \\
\hline Market work & $42.7 * *$ & 38.8 & 39.5 & $24.0 * *$ & $30.5 * *$ & 28.3 \\
\hline Household work & $12.8 * *$ & 14.7 & 15.4 & $27.9 * *$ & 23.2 & 23.8 \\
\hline Caregiving & 4.4 & 4.6 & 4.4 & $9.5 * *$ & 8.8 & 8.3 \\
\hline Education & $0.6 * *$ & $0.6 *$ & 0.3 & $1.3 * *$ & $0.8 * *$ & 0.6 \\
\hline Comm., relig. & $1.5 * *$ & 1.9 & 1.8 & $1.9 * *$ & $1.7 * *$ & 2.3 \\
\hline Leisure & $43.5 * *$ & 48.2 & 47.6 & $39.5 * *$ & $42.4 * *$ & 44.1 \\
\hline Sleep & $61.1 * *$ & 58.1 & 57.7 & $62.3 * *$ & 59.2 & 59.2 \\
\hline Other coded & $0.3 * *$ & 0.2 & 0.2 & 0.2 & $0.3 *$ & 0.2 \\
\hline Uncoded & 1.1 & 1.1 & 1.0 & $1.4 * *$ & 1.2 & 1.2 \\
\hline Observations & 5,084 & 2,128 & 27,533 & 5,977 & 2,668 & 34,780 \\
\hline \multicolumn{7}{|c|}{ YOUTHS (AGES 15-20 YEARS) AND FULL-TIME STUDENTS } \\
\hline Market work & 16.0 & $12.1 *$ & 14.2 & $15.8 *$ & $9.5 * *$ & 13.2 \\
\hline Household work & 9.7 & $7.8 * *$ & 9.1 & 14.2 & 14.7 & 13.7 \\
\hline Caregiving & 2.5 & 2.7 & 2.4 & 4.7 & 3.9 & 4.1 \\
\hline Education & 20.5 & $22.3 * *$ & 19.5 & $23.7 * *$ & $24.7 * *$ & 20.4 \\
\hline Comm., relig. & $1.3 *$ & 1.6 & 2.1 & 2.3 & 1.9 & 2.1 \\
\hline Leisure & $48.6 * *$ & 54.4 & 55.1 & $43.1 * *$ & $46.5 *$ & 48.7 \\
\hline Sleep & $67.7 * *$ & 65.3 & 64.1 & $62.1 * *$ & 64.9 & 64.2 \\
\hline Other coded & 0.4 & 0.2 & 0.3 & 0.2 & 0.4 & 0.2 \\
\hline Uncoded & 1.2 & 1.5 & 1.4 & 1.9 & 1.6 & 1.4 \\
\hline Observations & 496 & 764 & 4,003 & 497 & 719 & 4,725 \\
\hline \multicolumn{7}{|c|}{ OLDER AdUltS (AGES 65 AND HIGHER) AND RETIREES } \\
\hline Market work & $10.3 * *$ & 5.3 & 6.0 & 3.8 & $2.4 * *$ & 3.2 \\
\hline Household work & 21.0 & 21.8 & 22.5 & $32.2 * *$ & 30.3 & 30.3 \\
\hline Caregiving & 2.6 & $1.8 * *$ & 2.7 & 3.3 & $2.4 * *$ & 3.1 \\
\hline Education & 0.1 & 0.1 & 0.1 & 0.1 & 0.2 & 0.3 \\
\hline Comm., relig. & 2.7 & $2.5 *$ & 3.2 & 3.8 & $3.2 * *$ & 3.8 \\
\hline Leisure & $64.0 * *$ & $72.3 * *$ & 69.4 & $59.1 * *$ & $65.9 * *$ & 63.2 \\
\hline Sleep & $64.7 * *$ & 61.9 & 62.1 & $63.6 * *$ & $61.3 *$ & 62.0 \\
\hline Other coded & 0.4 & 0.3 & 0.2 & 0.1 & 0.2 & 0.2 \\
\hline Uncoded & 2.2 & 2.0 & 1.8 & 2.0 & 2.1 & 1.9 \\
\hline Observations & 665 & 1,110 & 6,904 & 1,131 & 1,708 & 11,246 \\
\hline
\end{tabular}


Notes: Author’s calculations from 2003-10 ATUS; estimates use sampling weights provided with data.

* Average weekly hours are different from U.S. natives with native parents at .05 level.

** Average weekly hours are different from U.S. natives with native parents at .01 level. 
Table 2. Weekly hours in different activities in the U.S. among working-age foreign-born adults by gender and country of origin, 2003-10

\begin{tabular}{|c|c|c|c|c|c|c|c|c|c|c|}
\hline & Mexico & Cuba & El Sal. & Canada & Germany & U.K. & India & Philippines & China & Other \\
\hline \multicolumn{11}{|c|}{ MEN } \\
\hline Market work & 42.0 & $50.2 *$ & $49.4 * *$ & 37.4 & 41.6 & 45.1 & $49.1 * *$ & $31.3 * *$ & 44.7 & 42.4 \\
\hline HH work & 13.1 & 11.9 & $10.6 *$ & 14.6 & 14.1 & 16.3 & $11.1 *$ & $18.3 * *$ & 11.6 & 12.3 \\
\hline Caregiving & 4.3 & 4.0 & 4.4 & 5.7 & 2.6 & 4.7 & 4.4 & $6.7 * *$ & $6.9 * *$ & 4.3 \\
\hline Education & 0.4 & 0.5 & 0.4 & 0.2 & 0.6 & 0.1 & 0.4 & $2.2 * *$ & $1.3 *$ & $0.8 * *$ \\
\hline Comm., rel. & 1.1 & 0.7 & 1.3 & 1.4 & 2.3 & 0.9 & $2.1 *$ & 0.4 & 0.3 & $2.0 * *$ \\
\hline Leisure & 43.0 & 43.7 & 41.6 & $50.3 * *$ & 44.4 & 43.2 & $39.8 *$ & 46.0 & 41.7 & 44.3 \\
\hline Sleep & 62.5 & $56.2 * *$ & $59.4 * *$ & $55.5 * *$ & 61.6 & $55.6 * *$ & $59.6 * *$ & 61.8 & 60.5 & $60.6 * *$ \\
\hline Observations & 1,800 & 131 & 183 & 99 & 60 & 92 & 305 & 125 & 120 & 2,169 \\
\hline \multicolumn{11}{|c|}{ WOMEN } \\
\hline Market work & 18.7 & $27.2 * *$ & $26.0 * *$ & $25.7 *$ & $30.2 * *$ & 22.9 & 19.8 & $33.1 * *$ & $31.2 * *$ & $27.0 * *$ \\
\hline HH work & 31.3 & $23.9 * *$ & 28.5 & $25.1 * *$ & 28.5 & 30.4 & $27.1 * *$ & $25.5 * *$ & $24.6 * *$ & $25.6 * *$ \\
\hline Caregiving & 10.6 & $7.8 *$ & $4.9 * *$ & 11.3 & $4.0 * *$ & $7.8 *$ & $12.9 *$ & $7.9 * *$ & 10.3 & $8.8 * *$ \\
\hline Education & 0.8 & 0.9 & 1.4 & 1.2 & 0.5 & 0.3 & 0.7 & 0.9 & 1.4 & $1.8 * *$ \\
\hline Comm., rel. & 1.8 & 1.3 & $2.9 *$ & 1.4 & 0.9 & 2.6 & 2.5 & 1.7 & 1.0 & 2.1 \\
\hline Leisure & 38.8 & $45.2 * *$ & 36.6 & $44.2 * *$ & $45.3 * *$ & $44.8 * *$ & 40.8 & 39.2 & 37.6 & 39.3 \\
\hline Sleep & 64.2 & $60.3 * *$ & 66.6 & $57.7 * *$ & $57.2 * *$ & $57.5 * *$ & 62.6 & $58.7 * *$ & $60.3 * *$ & $61.6 * *$ \\
\hline Observations & 2,024 & 164 & 201 & 126 & 99 & 113 & 258 & 266 & 152 & 2,574 \\
\hline
\end{tabular}

Note: Author’s calculations from 2003-10 ATUS for foreign-born adults aged 21-64 years who are not students or retired; estimates use sampling weights provided with data. 
* $\quad$ Average weekly hours are different from Mexican immigrants at .05 level.

** Average weekly hours are different from Mexican immigrants at .01 level 


\section{NOTES}

${ }^{1}$ The following passage from Münscher’s (1984, pp. 1236-7) interviews with working Turkish immigrant women in Munich illustrates these advantages.

Ayla S.'s day consists of work. Her work is at different places and under different conditions. She gets up at 5, makes breakfast for herself and the children, and starts at the hospital at 7. Her two children, aged eight and ten, attend school in the morning. At hospital, Ayla S. gives out the meals, tidies up and scrubs the floors from 7 to 1:30, and again from 4 to 6 , sometimes until 6:30. During lunch hour, she gets home by bus, does the shopping, cooks for the children and tidies up. She always has to hurry to get back to the hospital on time. From 6 to 8 p.m., she then cleans the floors in a chemical factory. If she works overtime, she cleans until 8:30. She takes the bus home and gets there at 9. By then, the children have had their meals she had cooked during lunch time. When she has to work on weekends, the children are on their own the whole day.

And what does she do in her 'spare time'? "Do the washing, ironing, tidying up, washing up a bit, cleaning a bit, again cook a bit, sew clothes for the children. Housework is never done in any case, never finishes. Must do something every day." She has been working like this for twelve years now. 
This passage not only reveals that Ayla S. devotes long hours to work outside the home but also that she is under considerable time pressure as she shoulders family responsibilities and navigates transportation constraints.

${ }^{2}$ In 2003 (the first year of the ATUS), approximately 3,400 households were selected for participation each month.

${ }^{3}$ More generally, a large number of studies that follow the Harmonized European Time Use Surveys guidelines collect diaries on multiple days from multiple household members (Eurostat, 2009). However, these studies do not always collect or release information on immigrant status.

${ }^{4}$ As a short-hand, the rest of the paper refers to third-and-higher-generation residents as third-generation residents.

${ }^{5}$ Table 1 lists unadjusted estimates. Regression-based adjustments for demographic characteristics lead to substantially similar results. 